\title{
PEMANFAATAN ICT DALAM MENINGKATKAN EFISIENSI SUMBER DAYA DI POLITEKNIK LP3I BANDUNG
}

\author{
Hadiansyah Ma'sum, S.Pd., S.T., M.Kom. \\ Dosen Program Studi Manajemen Informatika \\ Politeknik LP3I Bandung \\ E-Mail : kanghadiansyah@gmail.com
}

\begin{abstract}
Abstrak : Konsep Green ICT terkait kesinambungan alam dengan produk, layanan dan sistem manajemen TIK yang ramah lingkungan (eco-friendly). Adanya kepedulian terhadap lingkungan yang disertai tekanan dari konsumen, legislator serta kenaikan harga bahan bakar merupakan faktor pendorong penerapan Green ICT.
\end{abstract}

Green ICT merupakan sebuah konsep upaya mengurangi konsumsi energi dan sumber daya alam lainnya, serta mengurangi emisi karbon dan sampah yang dihasilkan dari kegiatan di bidang teknologi informasi dan komunikasi. Industri TIK gobal menyumbang emisi karbon sekitar 2\% dari jumlah total emisi karbon dunia. Emisi karbon tersebut berasal dari penggunaan perangkat TIK seperti PC, server, telepon kabel dan nirkabel, LAN, serta peralatan TIK lainnya.

Politeknik LP3I Bandung sebagai salah satu perguruan tinggi berbasis vokasi di Indonesia sudah melakukan implementasi dan adaptasi teknologi informasi dan komunikasi.

Kata Kunci : Green ICT, Pemanfaatn ICT, Efisiensi Sumber daya

\section{Pendahuluan}

Peranan teknologi informasi dan komunikasi dalam dunia pendidikan juga sangat besar, khususnya dalam hal penunjang proses belajar-mengajar dan efisiensi pekerjaan akademik maupun administratif. Penetrasi dan implementasi teknologi informasi dan komunikasi pada perguruan tinggi akan memberikan dampak yang sangat positif serta diharapkan memberikan efisiensi dan produktivitas yang tinggi dalam bidang akademik dan administratif. Selain itu, dengan implementasi dan adaptasi teknologi informasi dan komunikasi diharapkan juga agar perguruan tinggi tersebut mampu terus bersaing dalam kancah persaingan dunia pendidikan di tingkat Nasional bahkan Internasional.

Konsep Green ICT terkait kesinambungan alam dengan produk, layanan dan sistem manajemen TIK yang ramah lingkungan (eco-friendly). Adanya kepedulian terhadap lingkungan yang disertai tekanan dari konsumen, legislator serta kenaikan harga bahan bakar merupakan faktor pendorong penerapan Green ICT.

Green ICT merupakan sebuah konsep upaya mengurangi konsumsi energi dan sumber daya alam lainnya, serta mengurangi emisi karbon dan sampah yang dihasilkan dari kegiatan di bidang teknologi informasi dan komunikasi. Industri 
TIK gobal menyumbang emisi karbon sekitar 2\% dari jumlah total emisi karbon dunia. Emisi karbon tersebut berasal dari penggunaan perangkat TIK seperti PC, server, telepon kabel dan nirkabel, LAN, serta peralatan TIK lainnya.

Namun, pemanfaatan ICT yang digunakan di Politeknik LP3I Bandung belum diketahui sebarapa besar berpengaruhnya sehingga benar-benar dengan adanya penerapan ICT dapat meningkatkan efisiensi sumber daya yang ada.

\section{Tinjauan Pustaka}

\subsection{Pengertian Green ICT}

Penerapan Green ICT dengan pemakaian perangkat teknologi yang ramah lingkungan membantu mengurangi emisi karbon dibandingkan pemakaian perangkat TIK biasa. Pengaplikasian konsep Green ICT diharapkan dapat meningkatkan efisiensi energi untuk mendukung pelestarian lingkungan di sekitarnya.

Menurut Molla dalam Gholamreza Nazari dan Hooman Karim (2011) menyatakan bahwa Green IT adalah kemampuan organisasi untuk secara sistematis menerapkan kriteria keberlanjutan lingkungan hidup untuk mendesain, memproduksi, menggunakan sumber daya dan pembuangan limbah infrastruktur TI serta dalam komponen manusia dan manajerial yang ada dalam infrastruktur TI (Gholamreza Nazari, 2011).

\subsection{Sasaran Green ICT}

Dari suatu instansi yang menerapkan konsep Green IT akan didapat pengurangan konsumsi daya antara 5\% sampai $10 \%$ dari setiap perangkat komputer sampai dengan server dan perangkat lainnya. Hal ini juga berpengaruh dalam mengurangi biaya operasional lainnya yang terkait dengan hal pemeliharaan seperti penggunaan air conditioner yang dibutuhkan untuk pendingin / penjaga kestabilan perangkat, serta efisiensi tata letak server yang dibutuhkan, dimana dengan menggunakan server yang kecil dan optimalisasi perangkat server dengan cara virtualisasi akan mengurangi kebutuhan perangkat keras yang diperlukan. (Wawa Sundawa - 2008).

Selain dari sisi instansi maupun instansi besar, dari sisi rumah tangga pelaksanaan Green IT juga akan terasa manfaatnya. Dengan menggunakan perangkat yang hemat daya secara otomatis akan mengurangi biaya tagihan listriknya. Hal ini akan terasa menjadi lebih optimal ketika konsep Green IT sudah dikenal dan dilaksanakan sepenuhnya oleh sebagian masyarakat, sehingga manfaat dari pengurangan konsumsi daya tersebut akan sangat terasa besar.

\subsection{ICT dalam Kehidupan Masyarakat}

Peranan ICT dalam kehidupan masyarakat bisa dijabarkan sebagai berikut:

1. Di Rumah

Keberadaan komputer pribadi di rumah memberikan manfaat yang cukup banyak, misalnya membantu seseorang untuk melakukan hobi (games), membantu melakukan pekerjaan kantor di rumah, membantu melakukan 
proyek proyek kecil bersama keluarga, membantu anak mengerjakan pekerjaan rumah dari sekolah dan meng hubungi saudara dan temandengan email.

2. Dunia Usaha (perusahaan)

Dunia usaha merupakan kelompok yang mendapat manfaat yang paling besar dari TI. Apalagi sekarang berkembang alat alat yang disebut mobile technologi, seperti Personal Digital Assistant (PDA), laptop, Handphone dan sebagainya yang memungkin akses informasi oleh seseorang dimana saja.

3. Dunia Pendidikan

Dunia pendidikan tidak terlepas dari TI. Dunia pendidikan membutuhkan TI yang sama besarnya dengan dunia usaha, terutama berkaitan untuk meng akses informasi dan pengetahuaan.

4. Pelayanan Masyarakat

Pelayanan masyarakat umum (public service) terutama diIndonesia biasanya sering menjadi kendala karena sifatnya yang lambat, birokratis, dan berbelit-belit. TI membantu mempersingkat dan mempermudah pelayanan masyarakat.

\subsection{Komponen Dalam Teknologi Informasi dan Komunikasi}

Komponen-komponen dalam teknologi informasi dan komunikasi sebagai berikut:

1. Sistem Komputer

Sistem komputer memegang peranan penting dalam penerapan teknologi informasi, karena komputer adalah salah satu komponen TI. Komponen sistem komputer terdiri dari empat komponen : perangkat keras (hardware), perangkat lunak (software), data dan komponen komunikasi.

2. Jaringan dan Komunikasi Data Perkembangan teknologi komputer meningkat dengan cepat.

Dengan berkembangnya teknologi komputer dan komunikasi, model komputer tunggal yang melayani seluruh tugas komputasi suatu organisasi kini telah diganti dengan sekumpulan komputer yang terpisah pisah, tetapi saling berhubungan dalam melaksanakan tugasnya. Sistem seperti ini disebut jaringan komputer. Istilah jaringan komputer dapat diartikan sebagai suatu himpunan inter koneksi sejumlah komputer yang autonomous. Dalam membangun jaringan komputer diperusahaan/organisasi, ada beberapa keuntungan yang dapat diperoleh dalam hal hal resource sharing, reliabilitas tinggi, lebih ekonomis, skalabilitas, dan media komunikasi. Jaringan komputer, merupakan komponenutama dari suatu komunikasi data. Komunikasi Data adalah pertukaran data antara dua perangkat melalui media transmisi tertentu (misalnya : kabel).

3. Teknologi Internet dan Web Internet adalah kumpulan atau jaringan komputer yang ada diseluruh dunia.

Seiring dengan semakin berkembangnya jaringan internet diseluruh dunia maka jumlah situs web yang tersedia juga semakin meningkat. Hingga saat ini, jumlah halaman web yang bisa diakses melalui internet telah mencapai angka miliaran. Untuk memudahkan penelusuran halaman 
web, terutama untuk menemukan halaman yang mempunyai topik topik spesifik, dapat menggunakan suatu mesin pencari (search engine).

4. Sistem Multimedia dan Basis data Media mengacu kepada jenis informasi atau jenis representasi informasi, seperti data alfa numeric, image, audio, dan video.

\section{Metode Penelitian}

Metode yang digunakan dalam penelitian ini dapat dilihat pada gambar beriku ini:

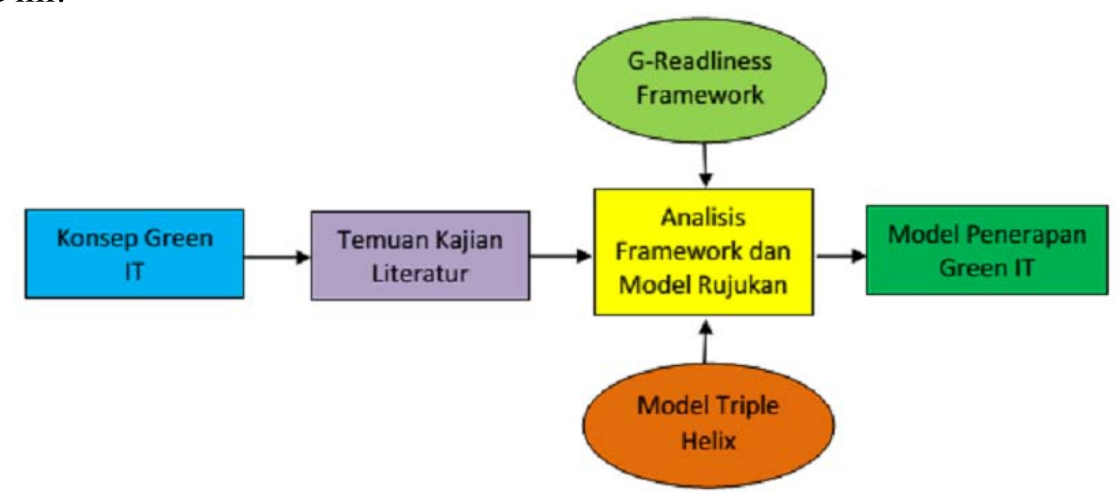

Gambar 3.1 Metode Penelitian

Framework yang digunakan sebagai rujukan utama dalam kajian ini adalah Connection Research - RMIT Green ICT Frame Work.

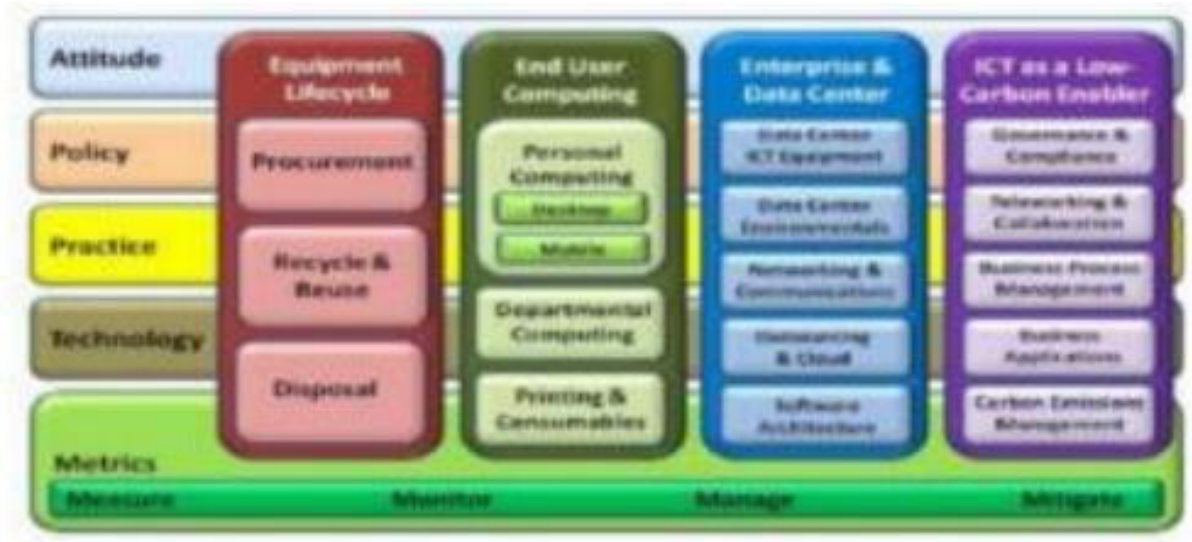

Gambar 3.2. Connection Research - RMIT Green ICT Framework (Research, 2010)

Pada Connection Research - RMIT Green ICT Framework memperlihatkan Green ICT dan keberlanjutan secara holistic. Pada framework tersebut terdapat 4 pilar vertical yang masing-masing spesifik, dan ada 5 komponen horizontal yang merupakan aksi yang menggambarkan secara terpisah pendekatan kearah vertikal. 


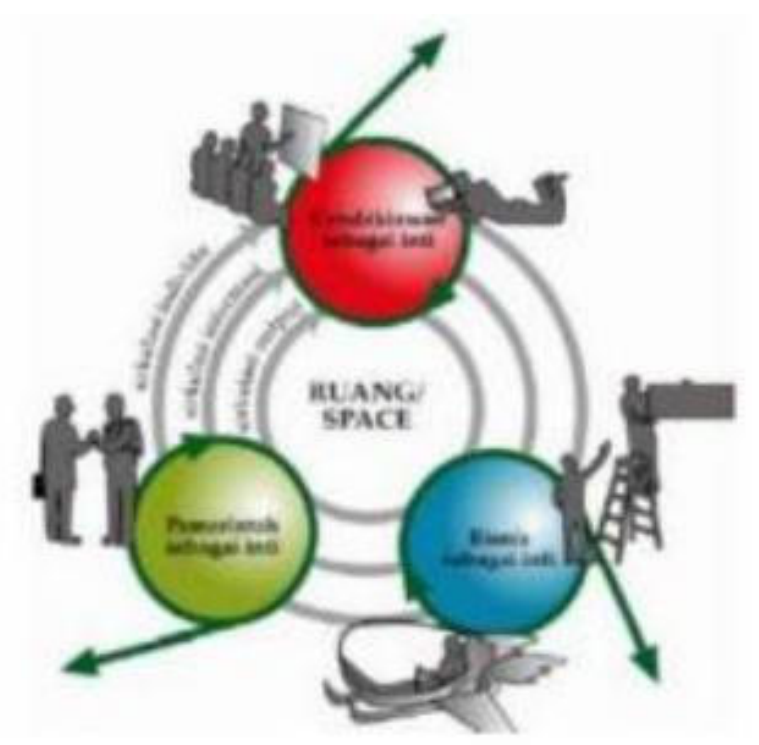

Gambar 3.3. Model pola interaksi Triple Helix (Perdagangan, 2008)

Pada model interaksi Triple Helix terlihat ada tiga actor yaitu cendekiawan, bisnis dan pemerintah. Triple Helix ini bertindak sebagai actor utama yang selalu bergerak melakukan sirkulasi untuk membentuk knowledge spaces. Ruang pengetahuan (knowledge spaces) merupakan tempat dimana ketiga actor sudah memiliki pemahaman dan pengetahuan yang setara yang akan mengarahkan ketiganya untuk membentuk consensus space, yaitu ruang kesempatan dimana ketiga actor mulai membuat kesempatan dan komitmen atas suatu hal yang akhirnya akan mengarahkan kepada terbentuknya innovation space. Sirkulasi ini selalu berusaha menciptakan keterbaruan (Perdagangan, 2008).

Framework serta model tersebut di atas dianalisis dalam prespektif penerapan Green IT pada Politeknik LP3I Bandung dengan prinsip-prinsip yang melekat pada setiap aksi dan inovasi.

\section{Hasil Dan Pembahasan}

Untuk lebih mengarah secara komprehensif dan efektif dari pelaksanaan Penerapan pemanfaatan ICT dalam meningkatkan efisiensi sumber daya di Politeknik LP3i Bandung dilakukan pendekatan holistik yang melingkupi empatbidang dalam pelaksanaannya yaitu:

1. Green Use: pengurangan konsumsi daya dari komputer dan perangkat TIK lainnya, serta penggunaan perangkat-perangkat tersebut dengan cara yang ramah lingkungan.

Untuk melaksanakan Green Use ini dengan cara :

a. Mengganti Personal Computer (PC) karyawan dan labkom dengan Notebook. Dengan perbandingan watt PC : Notebook $=450$ watt : 65 watt sama dengan $1: 7$. 
b. Mengganti Personal Computer (PC) presensi dosen dan mahasiswa dengan Thin Client. Dengan perbandingan watt PC : Thin Client $=450$ watt : 10 watt sama dengan $1: 45$.

c. Mengganti buku modul mata kuliah dengan multimedia ebook sehingga mahasiswa terbiasa menggunakan komputer.

Dalam hal ini peneliti menerangkan tentang mengganti Personal Computer (PC) dengan Notebook. Keuntungan dari penggunaan notebook yaitu:

a. Daya listrik lebih hemat dari pada PC, Perbandingan daya listrik PC : NB $=450$ watt $: 65$ watt sama dengan $1: 7$

b. Produktivitas lebih tinggi

c. Daya jual second lebih mahal

d. Kebutuhan ruang kecil

e. Konektivitas jaringan dinamis

f. Pengamanan saat darurat lebih mudah

Sampai dengan tahun 2014 PC yang digunakan di Politeknik LP3I Bandung terdiri dari :

a. PC Karyawan berjumlah 49 unit

b. PC Laboratorium Komputer berjumlah 3 lab dengan total 75 unit

\begin{tabular}{|c|l|c|c|c|c|}
\hline NO & \multicolumn{1}{|c|}{ KETERANGAN } & JENIS & JML & WATT & $\begin{array}{c}\text { TOTAL } \\
\text { WATT }\end{array}$ \\
\hline 1 & Komputer Karyawan & PC & 49 & 450 & 22.050 \\
\hline 2 & $\begin{array}{l}\text { Laboratorium } \\
\text { Komputer }\end{array}$ & PC & 75 & 450 & 33.750 \\
\hline \multicolumn{4}{|c|}{ TOTAL WATT } & \\
\hline
\end{tabular}

Jika semua PC diganti dengan Notebook maka Total Watt yang digunakan sebagai berikut :

\begin{tabular}{|c|l|c|c|c|c|}
\hline NO & KETERANGAN & JENIS & JML & WATT & $\begin{array}{c}\text { TOTAL } \\
\text { WATT }\end{array}$ \\
\hline 1 & Komputer Karyawan & NoteBook '14 & 49 & 65 & 3.185 \\
\hline 2 & $\begin{array}{l}\text { Laboratorium } \\
\text { Komputer }\end{array}$ & NoteBook '14 & 75 & 65 & 4.875 \\
\hline \multicolumn{4}{|l|}{ TOTAL WATT } \\
\hline
\end{tabular}

Dengan pergantian ini maka hemat penggunaan Sumber Daya Listrik sebesar 47.740 Watt dengan perhitungan sebagai berikut:

Rumus : TOTAL WATT PC - TOTAL WATT NOTEBOOK

$=55.800$ watt -8.060 watt

$=47.740$ watt 
2. Green Disposal: memperbaharui dan menggunakan kembali perangkat lama dan juga mendaur ulang perangkat elektronik yang sudah tidak dipakai lagi. Hal ini bisa dilaksanakan dengan cara melakukan evaluasi terhadap perangkat-perangkat hardware yang digunakan, untuk menggantikan perangkat-perangkat hardware tersebut dengan fitur yang lebih hemat energy atau jika ada keruksakan dengan salah satu hardware maka bisa digunakan hardware cadangan yang ada tanpa harus membeli yang baru.

3. Green Design: perencanaan penggunaan perangkat atau sistem informasi yang efisien terhadap daya dan ramah lingkungan.

Dengan pemanfaatan ICT di lingkungan kampus dari mulai proses penerimaan mahasiswa baru, sistem administrasi akademik, sistem administrasi keuangan, sistem informasi pembimbing akademik, dan lainlain. Menggunakan konsep paperless untuk meminimalkan penggunaan kertas yang sebelumnya penggunaan kertas diperusahaan sangat tinggi. Hal ini bisa mengurangi penggunaan bahan baku kertas .

4. Green Manufacturing: pembuatan komponen segala macam perangkat elektronik / peragkat TIK yang berdampak kecil atau bahkan tidak berdampak sama sekali terhadap lingkungan.

Dengan melaksanakan model implementasi Green Computing sebagai berikut :

1. Model Implementasi Environment Impact

Untuk melakukan implementasi dari faktor environment impact peneliti memberikan rekomendasi dengan langkah-langkah sebagai berikut:

Tabel 2 Konsep Model Implementasi ada Environment Impact

\begin{tabular}{|l|l|}
\hline \multicolumn{1}{|c|}{ Konsep Model } & \multicolumn{1}{|c|}{ Keterangan } \\
\hline $\begin{array}{l}\text { 1. Green } \\
\text { paperless }\end{array}$ & $\begin{array}{l}\text { Menggunakan konsep paperless untuk meminimalkan } \\
\text { penggunaan kertas yang sebelumnya penggunaan } \\
\text { kertas diperusahaan sangat tinggi. }\end{array}$ \\
\hline $\begin{array}{l}\text { 2. Menggunakan } \\
\text { konsep reduce }\end{array}$ & $\begin{array}{l}\text { Melakukan evaluasi terhadap perangkat-perangkat } \\
\text { hardware yang digunakan, untuk menggantikan } \\
\text { perangkat-perangkat hardware tersebut dengan fitur } \\
\text { yang lebih hemat energi. }\end{array}$ \\
\hline $\begin{array}{l}\text { 3. Perusahaan } \\
\text { mensosialisasik } \\
\text { an arti globlal } \\
\text { warming } \\
\text { kepada } \\
\text { karyawan }\end{array}$ & $\begin{array}{l}\text { Perusahaan diharapkan memberikan sosialisasi akan } \\
\text { dampak-dampak serta penyebab (khususnya } \\
\text { penggunaan perangkat IT) akan global warming kepada } \\
\text { karyawan, sehingga karyawan akan memiliki kesadaran } \\
\text { untuk menjaga lingkungan. }\end{array}$ \\
\hline
\end{tabular}

2. Model Implementasi Green Economy

Pengertian green economy atau ekonomi yang ramah lingkungan secara sederhana dapat artikan sebagai segala upaya yang dilakukan dengan menggunakan sumber daya yang digunakan untuk tujuan tertentu dengan memperhatikan dampak-dampak pada lingkungan.

Untuk melakukan implementasi dari faktor Green Economy peneniliti memberikan rekomendasi langkah-langkah sebagai berikut: 
Tabel 3 Konsep Model Implementasi Pada Green Economy

\begin{tabular}{|l|l|}
\hline \multicolumn{1}{|c|}{ Konsep Model } & \multicolumn{1}{|c|}{ Keterangan } \\
kenggunakan & $\begin{array}{l}\text { Perlu membuat kebijakan baru yang berhubungan } \\
\text { dengan penggunaan kembali semua perangkat } \\
\text { hardware yang masi digunakan dengan catatan } \\
\text { perangkat tersebut memilki fitur hemat energi dan } \\
\text { penggunaan kembali pada kertas yang masih } \\
\text { miliki halaman kosong. }\end{array}$ \\
\hline $\begin{array}{l}\text { 2. Evaluasi } \\
\text { penggunaan } \\
\text { energi listrik pada } \\
\text { ruang labkom. }\end{array}$ & $\begin{array}{l}\text { Perlu melakukan evaluasi terhadap penggunaan } \\
\text { energi listrik yang digunakan pada ruang } \\
\text { laboratorium komputer, untuk melihat tingkat } \\
\text { keefesienan dalam penggunaan energi lisrik. }\end{array}$ \\
\hline $\begin{array}{c}\text { 4.Menggunakan } \\
\text { teknologi } \\
\text { telecommuting }\end{array}$ & $\begin{array}{l}\text { Perusahaan perlu memperkenalkan teknologi } \\
\text { telecommuting pada karyawan disemua } \\
\text { department, dan dapat digunakan untuk } \\
\text { melakukan pertemuan jarak jauh tanpa harus } \\
\text { ketemu didalam menjalankan proses bisnis. }\end{array}$ \\
\hline
\end{tabular}

\section{Model Implementasi Green Awareness}

Green awareness atau kesadaran akan lingkungan secara sederhana dapat artikan sebagai pengertian yang mendalam pada diri seseorang atau sekelompok orang yang terwujud dalam pemikiran, sikap, dan tingkah laku yang mendukung pengembangan lingkunga, sehingga individu tersebut akan menjaga dan melesatarikan lingkungan tempat ia berada.

Untuk melakukan implementasi dari faktor green awareness peneniliti memberikan rekomendasi dengan langkah-langkah sebagai berikut:

Tabel 4 Model Implementasi Pada Green Awareness

\begin{tabular}{|l|l|}
\hline \multicolumn{1}{|c|}{ Konsep Model } & \multicolumn{1}{|c|}{ Keterangan } \\
\hline 1.Menggunakan konsep recyling & $\begin{array}{l}\text { Perlu membuat kebijakan baru } \\
\text { yang berhubungan dengan } \\
\text { pengolahan kembali pada } \\
\text { perangkat-perangkat hardware } \\
\text { bagian dalam untuk digunakan } \\
\text { kembali. }\end{array}$ \\
\hline $\begin{array}{l}\text { 2. Menggunakan konsep } \\
\text { power management }\end{array}$ & $\begin{array}{l}\text { Perlu melatih para karyawannya } \\
\text { dengan manajemen daya dengan } \\
\text { tujuan para karyawan mengerti } \\
\text { pada sistem operasi yang mengatur } \\
\text { penggunaan sumber daya pada } \\
\text { komputer. }\end{array}$ \\
\hline $\begin{array}{l}\text { 3. Berpatisipasi dalam menjaga } \\
\text { lingkungan dari pencemaran }\end{array}$ & $\begin{array}{l}\text { Perusahaan perlu mengembangkan } \\
\text { berpatisipasi untuk pelestarian } \\
\text { lingkungan yang berguna untuk }\end{array}$ \\
\hline
\end{tabular}




\begin{tabular}{|l|l|}
\hline & $\begin{array}{l}\text { mengurangi emisi karbon dioksida } \\
(\mathrm{CO} 2) .\end{array}$ \\
\hline
\end{tabular}

\section{Model Implementasi Social of Rejection}

Social of rejection atau penolakan akan sosial secara sederhana dapat diartikan sebuah penolakan sosial yang terjadi ketika individu/organisasi sengaja dikeluarkan dari hubungan sosial atau interaksi sosial dikarenakan ketidaksesuaian.

Untuk melakukan implementasi dari faktor social of rejection peneniliti akan memberikan rekomendasi dengan langkah-langkah sebagai berikut:

Tabel 5 Konsep Model Implementasi Pada Social of Rejection

\begin{tabular}{|c|c|}
\hline Konsep Model & Keterangan \\
\hline $\begin{array}{l}\text { 1. Melakukan efficient } \\
\text { resource }\end{array}$ & $\begin{array}{l}\text { Perusahaan perlu melakukan evaluasi } \\
\text { terhadap penggunaan energi didalam } \\
\text { perusahaan, dalam hal ini perusahaan } \\
\text { belum menggunakan konsep virtualisasi } \\
\text { pada server sehingga belumnya } \\
\text { efisiensinya dalam penggunaan sumber } \\
\text { daya pada energi listrik dan perusahaan } \\
\text { perlu menggunakan sumber daya energi } \\
\text { alternatif sebagai langkah untuk melakukan } \\
\text { efesient didalam penggunaan sumber daya } \\
\text { energi listrik. }\end{array}$ \\
\hline $\begin{array}{l}\text { 2. Melakukan corporate } \\
\text { social responbility } \\
\text { (CSR) }\end{array}$ & $\begin{array}{l}\text { Perusahaan perlu aktif dalam berkontribusi } \\
\text { dalam program menjaga lingkungan seperti } \\
\text { melakukan penanaman pohon, mengajak } \\
\text { gerakan hemat energi. }\end{array}$ \\
\hline $\begin{array}{l}\text { 3.Mengurangi emisi } \\
\text { karbondioksida } \mathrm{CO} 2\end{array}$ & $\begin{array}{l}\text { Melakukan pengembangan dengan } \\
\text { teknologi yang ada dengan Praktek-praktek } \\
\text { Green Computing untuk menggurangi } \\
\text { dampak dari penggunaan ICT (Information } \\
\text { Communication Technology) yang semakin } \\
\text { tinggi. }\end{array}$ \\
\hline
\end{tabular}

\section{Kesimpulan}

Dari hasi penelitian yang telah dilakukan dapat disimpulkan bahwa Green IT memiliki peran penting untuk efisiensi sumber daya yang ada di Politeknik LP3I Bandung. Keterbukaan jajaran pimpinan dengan karyawan juga dapat dimanfaatkan untuk mempengaruhi perubahan pola piker dari yang tidak ramah lingkungan menjadi ramah lingkungan. 
Pemanfaatan Green IT dapat dilihat dari berbagai perspektif seperti dimensi kerja, terdapat berbagai besaran tekur (waktu, energy, biaya, dampak terhadap lingkungan, dll) yang diupayakan untuk ditingkatkan atau dikurangi dalam mewujudkan Green IT.

Dari Perspektif metode, Green IT dapat dilakukan dengan cara mengurangi, guna ulang, daur ulang, virtualisasi, optimasi, mengukur, dan bahkan dengan memberikan informasi yang tepat dan cukup untuk membuat seorang memutuskan berperilaku lebih hijau.

Mengupayakan Green IT yang berhasil guna bukanlah perkara yang mudah. Green IT membutuhkan keterlibatan dan dukungan dari berbagai pihak mulai dari vendor, pemerintah, hingga pengguna, baik individu, kelompok, maupun korporat. Terlebih lagi, hambatan terbesar ada pada perilaku pengguna ICT itu sendiri. Tetapi jika perilaku Hijau pengguna telah terbentuk, faktor pengguna dapat menjadi factor penentu terbesar keberhasilan Green IT. Oleh karena diperlukan penelitian dan kerja ekstensif, bagaimana ICT berkontribusi bagi pembentukan perilaku masyarakat yang ramah lingkungan. Teknologi dapat mengubah perilaku penggunanya.

\section{Daftar Pustaka}

[1] Budihardjo, Ir. Eko, Prof. M.Sc, (2003), Kota dan Lingkungan, United Nation, University Pers Jakarta, LP3ES

[2] Erwin. (2011, Januari 19). Mastel Dukung Program ICT, Jakarta

[3] Gholamreza Nazari, H.K. (2011), Mission Possible : Becoming Green and Sustainable An Empirical Study on Green IT Adoption and Underlying.

[4] Haryati, Dra, M.I.Kom, (2012), Penerapan Green Computing di Provinsi Jawa Barat, Kementerian Riset dan Teknologi.

[5] Lumanto, Rudi. Dr, (2005), Komunikasi Dan Informatika Indonesia Buku Putih 2012, Kementerian Komunikasi dan Informatika Republik Indonesia.

[6] Mien R. Uno, (2011), Buku Pintar Etika Hijau, PT. Gramedia Pustaka Utama.

[7] Mayor Caj, Drs. Wendrizal, (2011), Program Toba Go Green Untuk Masyarakat. Toba Go Green-Kodam I/Bukit Barisan.

[8] Maria Ratnaningsing, Peran Perkantoran Dalam Penerapan Green Office, BPH YPT Tarakanita

[9] Prasetya Fandi Hantoro, (2012), Implementasi Green Computing Untuk Keberlangsungan Proses Bisnis Pada Pt. Fujitsu Indonesia, Jurnal SI Working Paper.

[10] S, Murugesan. (2007). Going Green with IT: Your Responsibility towardEnvironmental Sustainability. USA: Cutter Business-IT Strategies Executive Report, vol. 10, no. 8,.

[11] Stollenmayer, P. (2011). How The Earth can Benefit from Green ICT. USA: Green ICT, 2, 8.

[12] Wawa Sundawa (2008). Green Computing. Jakarta: PT. Dian Digital Media.

[13] Wallace and Webber. (2009). IT Governance Policies \& Procedures. United States of America: Aspen Publisher. 
[14] Webber, L.,\& Wallace, M. (2009). Green Tech: How to Plan and Implement Sustainable IT. Solutions. New York: AMACOM 